\title{
The importance of genetic research in cases of severe male factor infertility: A case of 46,XX testicular disorder of sex development
}

\author{
Dalana Faleiro ${ }^{1,2}$, Betina Iser ${ }^{1}$, André Anjos da Silva1,3, Marcos Alexandre Höher ${ }^{1,3}$ \\ ${ }^{1}$ Hospital Bruno Born (Centro de Reprodução Humana Bruno Born) \\ 2Programa de Pós-Graduação em Ciências da Saúde-Ginecologia e Obstetrícia, Universidade Federal do Rio \\ Grande do Sul (UFRGS), Porto Alegre, Brazil \\ 3Programa de Pós-Graduação em Ciências Médicas, Universidade do Vale do Taquari - Univates, Lajeado, Brazil
}

\begin{abstract}
$46, \mathrm{XX}$ testicular disorder of sex development is a rare syndrome characterized by an inconsistency between genotype and phenotype. Affected individuals present variant genitalia between male and ambiguous, nonfunctional testicles, non-obstructive azoospermia, generally accompanied by hypergonadotropic hypogonadism, a condition known for high levels of gonadotrophic hormones. In some cases, disorders of sexual development are diagnosed during puberty. However, a significant number of individuals show physical characteristics common to males that are not clinically suspicious. As a result, patients with the condition may remain undiagnosed. Many individuals with the condition are diagnosed as adults, due to infertility. The present study discusses the case of an individual who underwent karyotyping for sterility and was found to be a $46, X X$ male. Despite having a female karyotype, the presence of the sex-determining region $Y$ gene explains the manifestation of masculine secondary sex characteristics. This report highlights the importance of genetic evaluation, considering that carriers may present significant complications resulting from the disorder. Based on correct diagnosis, it is possible to improve a carrier's quality of life through multidisciplinary approaches and help them achieve pregnancy through assisted reproductive technology treatments.
\end{abstract}

Keywords: 46,XX male, de la Chapelle syndrome, SRY gene, male infertility, case report

\section{INTRODUCTION}

Infertility is a health issue that affects $15-20 \%$ of couples of reproductive age characterized by the inability to achieve pregnancy after 12 months of having sex without the use of contraceptive methods (Datta et al., 2016; Gilany et al., 2015; Szczykutowicz et al., 2019). Male factor infertility accounts for $20-60 \%$ of the cases, appearing in isolation or in association with female infertility (Szczykutowicz et al., 2019; Alahmar, 2019; Nardelli et al., 2014; Ferlin et al., 2007). The substantial involvement of males in cases of conjugal infertility demonstrates the importance of assessing the male reproductive system and the conditions that influence reproductive capacity, including functions related to the endocrine system, spermatogenesis, genetic changes and processes involved in fertilization (Halder et al., 2017). Azoospermia, frequently seen in daily clinical practice and characterized by the complete absence of sperm in the ejaculate, accounts for $10-15 \%$ of male infertility cases (Katz et al., 2017; Hamada et al., 2013; Krausz \& Riera-Escamilla, 2018). Genetic changes related to chromosomal abnormalities have been found in $15 \%$ of males with non-obstructive azoospermia (Krausz \& Riera-Escamilla, 2018).

$46, X X$ testicular disorder of sexual development (DSD), also known as de la Chapelle syndrome, is a rare condition ( 1 in 20,000-30,000 male individuals) in which a discrepancy exists between the phenotype and genotype of an individual (Gilany et al., 2015; Krausz \& Riera-Escamilla, 2018; De La Chapelle et al., 1964; Mohammadpour Lashkari et al., 2016). The main characteristics of individuals with 46,XX testicular DSD are having male external genitalia and azoospermia. Patients with the condition may also present with cognitive problems, sexual dysfunction, and reduced hair distribution (Bianco et al., 2011; Délot \& Vilain, 2015). Considering the importance of diagnosis and the repercussions of the condition in the affected individual's life, it is crucial to report cases to the scientific and medical communities in order to improve diagnosis, treat, and follow patients with the condition. This paper reports the case of an individual with $46, X X$ testicular DSD diagnosed at a center for human reproduction $(\mathrm{CRH})$ in Southern Brazil.

\section{PATIENT INFORMATION AND DISCUSSION}

A couple suffering with infertility for two years went to a $\mathrm{CRH}$ in Southern Brazil. Although the male partner in the couple had azoospermia, the causes of his condition had not been investigated and the couple was unaware of the chromosomal alteration that he had. The Research Ethics Committee approved the study (Plataforma Brasil certificate no. 45463021500005310) and the patient gave consent to having the case published.

The patient was a $183-\mathrm{cm}$ tall male Caucasian weighing $100 \mathrm{Kg}$ with a phenotype that is typically associated with having a eunuchoid body habitus, i.e., increased atypical fat distribution and reduced virilization. Individuals with de la Chapelle syndrome have both female and male physical characteristics, with greater amounts of fatty body mass in relation to lean body mass (Damiani et al., 2005; Majzoub et al., 2017), as observed in the individual described in this case report.

The patient in question had a history of surgical correction of gynecomastia performed at the age of 27 . Physical examination revealed he had a small penis and reduced pubic hair. The urinary system showed no abnormalities. The patient had testicular alterations, and ultrasound examination was performed in other areas of the scrotal pouch to check for possible anatomical lesions and malformations. Both testicles were atrophic, heterogeneous, and considerably reduced in volume. The echogenic areas within them were suggestive of fibrosis. The right testicle was located in the inguinal canal (cryptorchidism), measuring $1.4 \times 1.0 \times 0.9 \mathrm{~cm}$, with a volume of $0.7 \mathrm{~mL}$. The left testicle was located in the scrotum, measuring $1.3 \times 1.0$ $x 1.0 \mathrm{~cm}$, with a volume of $0.7 \mathrm{~mL}$. The structures of the epididymides did not show any noticeable changes. A subtle reduction of hair distribution was observed in physical examination. These characteristics described above were observed in cases of 46,XX testicular DSD published by Majzoub et al. (2017) in a literature review. The authors described the signs and symptoms of 46 men diagnosed with de la Chapelle Syndrome, which included sexual dysfunction, reduced hair distribution, and gynecomastia in $21 \%(4 / 19), 26.6 \%(8 / 30)$, and $40 \%(12 / 30)$ of the subjects. Less frequent abnormalities included undescended 
testicles (cryptorchidism) and hypospadias (Majzoub et al., 2017). Semen analysis was conducted after three days of abstinence. Decreased viscosity and azoospermia were observed in the samples, whereas the rest of the characteristics were within the parameters of normality (WHO, 2010). In addition, hormonal tests were performed using a chemiluminescence technique to analyze the patient's serum sample. Hormonal analyses revealed elevated levels of follicle stimulating hormone (FSH) and luteinizing hormone $(\mathrm{LH})$. Free testosterone (FT) was below the expected level, while serum levels of prolactin and sex hormone binding globulin (SHBG) were within the normal range (Table 1 ). These results are typically seen in hypergonadotropic hypogonadism $(\mathrm{HH})$ patients, thus showing that subjects with 46, XX testicular DSD usually develop HH (Baziz et al., 2016; Chen et al., 2019; Shi \& Martin, 2000).

In addition to the results and reported characteristics, subjects with 46,XX testicular DSD exhibit testicular development in the absence of the $Y$ chromosome (Bianco et al., 2011). Thus, peripheral blood G-band karyotyping was performed. A cytogenetic study revealed a 46, XX chromosomal constitution (Figure 1).

In reported sequences, the sex-determining region $Y$ (SRY) gene is present in about $80 \%$ of individuals with de la Chapelle syndrome, as a result of the translocation of a fragment of the $Y$ chromosome during parental spermatogenesis (Majzoub et al., 2017; Albu et al., 2019; Vorona et al., 2007). For the patient in question, real-time polymerase chain reaction analysis indicated the presence of the SRY gene. This gene is responsible for testicular development and regulation of the expression of genes such as SOX9 and DAX1, which play important roles in sexual determination, cell differentiation (Leydig cells, Sertoli cells, sperm), vascularization, and testicular cord development (Terribile et al., 2019; Barrionuevo \& Scherer, 2010; Larney et al., 2014; She \& Yang, 2017). Therefore, individuals with $46, X X$ testicular DSD possessing the SRY gene have male characteristics.

In situations where the SRY gene is not present in individuals with $46, X X$ testicular DSD, patients present varying degrees of masculinization. Mechanisms that might explain this phenotype include changes in genes related to sexual development (e.g., SOX9 and DAX1) or the activation of testicular differentiation cascades, occult Y-chromosome mosaicism limited to gonadal tissue or eliminated during development (Bianco et al., 2011; De La Chapelle, 1987; Croft et al., 2018; Bertalan et al., 2019; Rizvi, 2008).

When improperly investigated, it is difficult to diagnose $46, X X$ testicular DSD in phenotypically normal males. Identification of the condition can be performed during puberty, since approximately a third of the patients develop gynecomastia. However, individuals are often diagnosed with $46, X X$ testicular DSD male during infertility investigation, since all XX men are sterile (Majzoub et al., 2017; Terribile et al., 2019).

Once diagnosis was confirmed and the implications of having de la Chapelle syndrome were explained to the patient, a multidisciplinary approach consisting of genetic counseling, clinical management (hormone supplementation), psychological support, and referral for assisted reproductive technology treatments (in vitro fertilization or intrauterine insemination with donor semen) was offered to the couple. In addition, follow-up pelvic imaging to assess the presence of remaining Müllerian ducts (to avoid morbidities such as infections or urinary incontinence) and surgical removal of the gonads to avoid neoplastic transformation (gonadoblastoma) of dysgenetic gonads, since it may occur in about 30\% of cases (Adrião et al., 2020), were recommended.

This paper reported a rare case of $46, X X$ testicular DSD diagnosed from the investigation of male factor infertility and emphasized the importance of producing an adequate diagnosis, performing thorough clinical and laboratory evaluation, and following up with assisted reproductive technology treatments with donor semen.

\section{ACKNOWLEDGMENTS}

We would like to thank Editage (www.editage.com) for English language editing.

\section{CONFLICT OF INTEREST}

The authors have no conflict of interest to declare.

\section{Corresponding author:}

Dalana Faleiro

Hospital Bruno Born

Centro de Reprodução Humana Bruno Born

Lajeado - Rio Grande do Sul - Brazil

E-mail: dalanafaleiro1@gmail.com

Table 1. Clinical and laboratory data of a patient with $46, X X$ testicular DSD.

\begin{tabular}{|l|c|c|}
\hline Analyzed parameters & Data & $\begin{array}{c}\text { Serum levels considered } \\
\text { normal for adult men }\end{array}$ \\
\hline Age & 38 years & \\
\hline Height & $183 \mathrm{~cm}$ & \\
\hline External genitalia & Male & \\
\hline Testicles & Atrophic & $0.95-11.95 \mathrm{mUI} / \mathrm{mL}$ \\
\hline FSH* & $23.81 \mathrm{mUI} / \mathrm{mL}$ & $0.57-12.07 \mathrm{mUI} / \mathrm{mL}$ \\
\hline LH** & $17.67 \mathrm{mUI} / \mathrm{mL}$ & $2.1-17.7 \mathrm{ng} / \mathrm{ml}$ \\
\hline PRL*** & $8.7 \mathrm{ng} / \mathrm{ml}$ & $13.2-89.5 \mathrm{nmol} / \mathrm{L}(\mathrm{age}: 20-70)$ \\
\hline SHBG**** & $31.8 \mathrm{nmol} / \mathrm{L}$ & $3.4-24.6 \mathrm{ng} / \mathrm{dl}(\mathrm{age:}: 17-40)$ \\
\hline FT***** & $2.329 \mathrm{ng} / \mathrm{dl}$ & \\
\hline
\end{tabular}

*Follicle stimulating hormone (FSH); **luteinizing hormone (LH); ***prolactin (PRL); ****sex hormone-binding globulin $(\mathrm{SHBG}) ; * * * * *$ free testosterone (FT). 


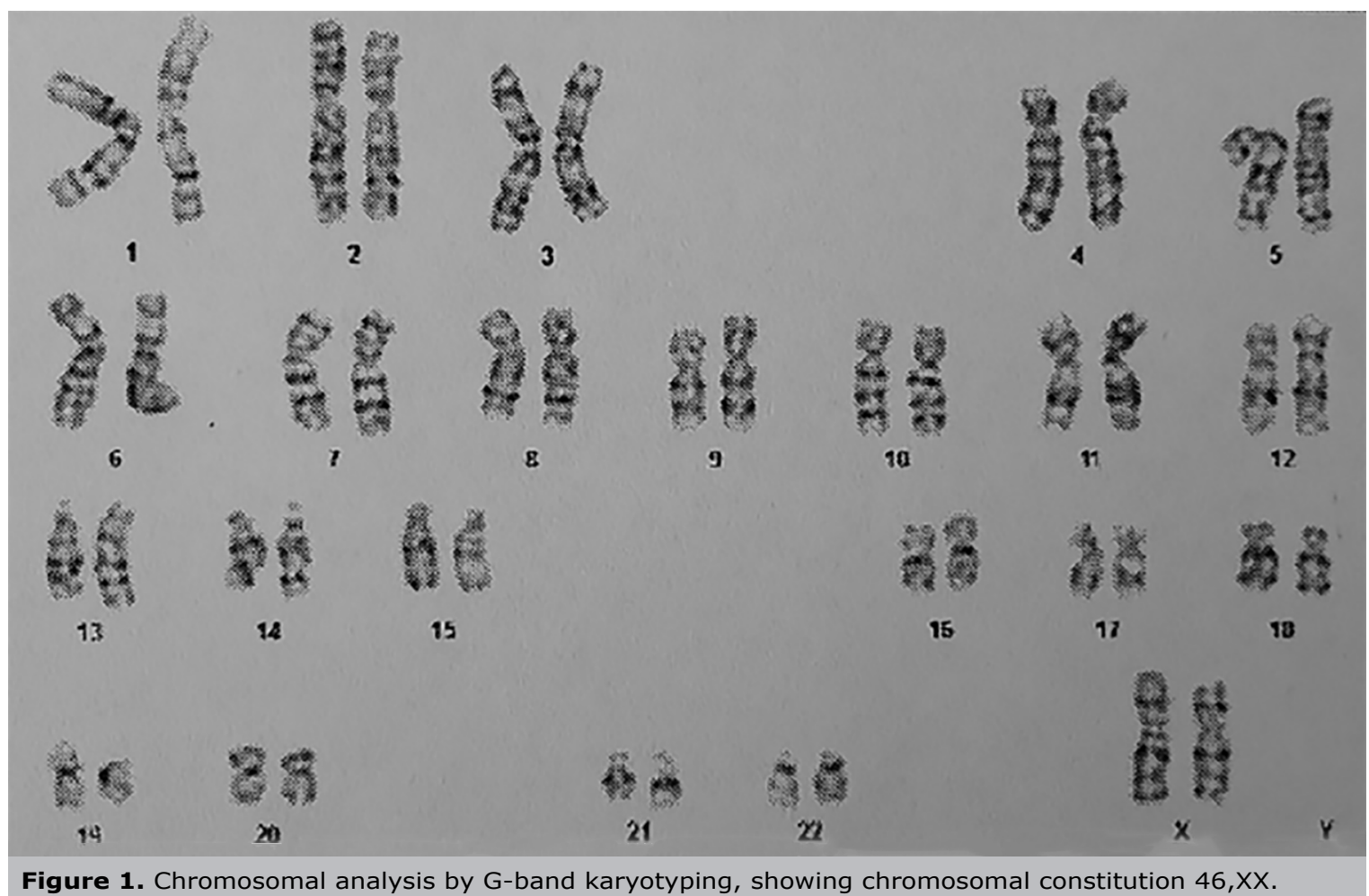

\section{REFERENCES}

Adrião M, Ferreira S, Silva RS, Garcia M, Dória S, Costa C, Castro-Correia C, Fontoura M. 46,XX male disorder of sexual development. Clin Pediatr Endocrinol. 2020;29:43-5. PMID: 32029971 DOI: 10.1297/cpe.29.43

Alahmar AT. Role of Oxidative Stress in Male Infertility: An Update Review. J Hum Reprod Sci. 2019;12:4-18. PMID: 31007461 DOI: $10.4103 /$ jhrs.JHRS_150_18

Albu C, Albu D, Muşat AR, Stancu IG, Albu ŞD, Pătraşcu A, Gogănău AM. The crucial role of SRY gene in the determination of human genetic sex: 46,XX disorder of sex development. Rom J Morphol Embryol. 2019;60:1311-6. PMID: 32239110

Barrionuevo F, Scherer G. Sox E genes: SOX9 and SOX8 in mammalian testis development. Int J Biochem Cell Biol. 2010;42:433-6. PMID: 19647095 DOI: 10.1016/j.biocel.2009.07.015

Baziz M, Hamouli-Said Z, Ratbi I, Habel M, Guaoua S, Sbiti A, Sefiani A. Cytogenetic Investigation in a Group of Ten Infertile Men with Non-Obstructive Azoospermia: First Algerian 46, XX Syndrome. Iran J Public Health. 2016;45:73947. PMID: 27648416

Bertalan R, Bencsik Z, Mezei P, Vajda Z, Butz H, Patócs A. Novel frameshift mutation of the NR0B1(DAX1) in two tall adult brothers. Mol Biol Rep. 2019;46:4599-604. PMID: 31280422 DOI: $10.1007 /$ s11033-019-04688-9

Bianco B, Christofolini DM, Ghersel FR, Gava MM, Barbosa CP. XX testicular disorder of sex differentiation: case report. Einstein (Sao Paulo). 2011;9:394-6. PMID: 26761113 DOI: $10.1590 / s 1679-45082011$ rc1862
Chen T, Tian L, Wu F, Xuan X, Ma G, Tang R, Lu J. Clinical and genetic analysis in males with $46, X X$ disorders of sex development: A reproductive centre experience of 144 cases. Andrologia. 2019;51:e13232. PMID: 30623467 DOI: 10.1111 /and.13232

Croft B, Ohnesorg T, Hewitt J, Bowles J, Quinn A, Tan J, Corbin V, Pelosi E, van den Bergen J, Sreenivasan R, Knarston I, Robevska G, Vu DC, Hutson J, Harley V, Ayers $\mathrm{K}$, Koopman $\mathrm{P}$, Sinclair A. Human sex reversal is caused by duplication or deletion of core enhancers upstream of SOX9. Nat Commun. 2018;9:5319. PMID: 30552336 DOI: 10.1038/s41467-018-07784-9

Damiani D, Guedes DR, Damiani D, Dichtchekenian V, Coelho Neto JR, Maciel-Guerra AT, Guerra-Júnior G, Mello MP, Setian N. Homem XX: relato de três casos na faixa etária pediátrica. Arq Bras Endocrinol Metab. 2005;49:7982. DOI: $10.1590 /$ S0004-27302005000100010

Datta J, Palmer MJ, Tanton C, Gibson LJ, Jones KG, Macdowall W, Glasier A, Sonnenberg $P$, Field N, Mercer $\mathrm{CH}_{\text {, }}$ Johnson AM, Wellings K. Prevalence of infertility and help seeking among 15000 women and men. Hum Reprod. 2016;31:2108-18. PMID: 27365525 DOI: 10.1093/humrep/dew 123

De La Chapelle A, Hortling $H$, Niemi M, Wennstrom J. XX Sex Chromosomes in a Human Male First Case. Acta Med Scand. 1964;175:25-8. PMID: 14154995 DOI: $10.1111 /$ j.0954-6820.1964.tb04630.x

De La Chapelle A. The Y-chromosomal and autosomal testis-determining genes. Development. 1987;101:33-8. PMID: 3503720 DOI: 10.1242/dev.101.Supplement.33 
Délot EC, Vilain EJ. Nonsyndromic 46,XX Testicular Disorders of Sex Development. 2003 Oct 30 [updated 2015 May 7]. In: Adam MP, Ardinger HH, Pagon RA, Wallace SE, Bean LJH, Stephens K, Amemiya A, eds. GeneReviews ${ }^{\circledR}$. Seattle (WA): University of Washington; 2015.

Ferlin A, Raicu F, Gatta V, Zuccarello D, Palka G, Foresta C. Male infertility: role of genetic background. Reprod Biomed Online. 2007;14:734-45. PMID: 17579990 DOI: 10.1016/ S1472-6483(10)60677-3

Gilany K, Minai-Tehrani A, Savadi-Shiraz E, Rezadoost $\mathrm{H}$, Lakpour $\mathrm{N}$. Exploring the human seminal plasma proteome: an unexplored gold mine of biomarker for male infertility and male reproduction disorder. J Reprod Infertil. 2015;16:61-71. PMID: 25927022

Halder A, Kumar P, Jain M, Kalsi AK. Genomics: Tool to predict and prevent male infertility. Front Biosci (Schol Ed). 2017;9:448-508. PMID: 28410128 DOI: $10.2741 / s 496$

Hamada AJ, Esteves SC, Agarwal A. A comprehensive review of genetics and genetic testing in azoospermia. Clinics. 2013;68:39-60. PMID: 23503954 DOI: 10.6061/clinics/2013(Sup01)06

Katz DJ, Teloken P, Shoshany O. Male infertility - The other side of the equation. Aust Fam Physician. 2017;46:641-6. PMID: 28892594

Krausz C, Riera-Escamilla A. Genetics of male infertility. Nat Rev. 2018;15:369-84. PMID: 29622783 DOI: 10.1038/ s41585-018-0003-3

Larney C, Bailey TL, Koopman P. Switching on sex: transcriptional regulation of the testis-determining gene Sry. Development. 2014;141:2195-205. PMID: 24866114 DOI: 10.1242/dev. 107052

Majzoub A, Arafa M, Starks C, Elbardisi H, Al Said S, Sabanegh E. 46 XX karyotype during male fertility evaluation; case series and literature review. Asian J Androl. 2017;19:168-72. PMID: 27297128 DOI: 10.4103/1008$682 \times .181224$

Mohammadpour Lashkari F, Totonchi M, Zamanian MR, Mansouri Z, Sadighi Gilani MA, Sabbaghian M, Mohseni Meybodi A. 46,XX males: a case series based on clinical and genetics evaluation. Andrologia. 2016;49:1-7. PMID: 27882599 DOI: $10.1111 /$ and. 12710
Nardelli AA, Stafinski T, Motan T, Klein K, Menon D. Assisted reproductive technologies (ARTs): evaluation of evidence to support public policy development. Reprod Health. 2014;11:76. PMID: 25376649 DOI: 10.1186/1742-4755$11-76$

Rizvi AA. 46, XX man with SRY gene translocation: cytogenetic characteristics, clinical features and management. Am J Med Sci. 2008;335:307-9. PMID: 18414071 DOI: 10.1097/MAJ.0b013e31811ec1b4

She ZY, Yang WX. Sry and SoxE genes: How they participate in mammalian sex determination and gonadal development? Semin Cell Dev Biol. 2017;63:13-22. PMID: 27481580 DOI: $10.1016 /$ j.semcdb.2016.07.032

Shi Q, Martin RH. Aneuploidy in human sperm: a review of the frequency and distribution of aneuploidy, effects of donor age and lifestyle factors. Cytogenet Cell Genet. 2000;90:219-26. PMID: 11124518 DOI: $10.1159 / 000056773$

Szczykutowicz J, Kałuża A, Kaźmierowska-Niemczuk $M$, Ferens-Sieczkowska M. The Potential Role of Seminal Plasma in the Fertilization Outcomes. Biomed Res Int. 2019;2019:5397804. PMID: 31531356 DOI: $10.1155 / 2019 / 5397804$

Terribile M, Stizzo M, Manfredi C, Quattrone C, Bottone F, Giordano DR, Bellastella G, Arcaniolo D, De Sio M. 46, XX Testicular Disorder of Sex Development (DSD): A Case Report and Systematic Review. Medicina. 2019;55:371. PMID: 31336995 DOI: 10.3390/medicina55070371

Vorona E, Zitzmann M, Gromoll J, Schüring AN, Nieschlag $E$. Clinical, endocrinological, and epigenetic features of the 46, XX male syndrome, compared with 47, XXY Klinefelter patients. J Clin Endocrinol Metab. 2007;92:3458-65. PMID: 17579198 DOI: $10.1210 /$ jc. $2007-0447$

WHO - World Health Organization. WHO laboratory manual for the examination and processing of human semen. 5th ed. Geneva: WHO; 2010. 